\title{
The Effect of Collaborative-Based Inquiry Learning Model and Science Process Skills towards Cognitive Ability of Elementary School Students
}

\author{
Jenny Lilawati \\ Basic Education Study Program Postgraduate \\ Universitas Negeri Medan \\ Medan, Indonesia \\ jennylilawati@gmail.com \\ Retno Dwi Suyanti \\ Department of Mathematics and Natural Science \\ Universitas Negeri Medan \\ Medan, Indonesia \\ dwihanna@yahoo.com \\ Wildansyah Lubis \\ Department of Education \\ Universitas Negeri Medan \\ Medan, Indonesia \\ willys1158@gmail.com
}

\begin{abstract}
The aim of this study is to determaine: whether the students cognitive ability taught by collaborative-based inquiry learning model better than students taught by direct instruction model, whether the students cognitive ability with high science process skills is better than students with low science process skills, and whether there is interaction between the two learning model with the level of science process skills influencing students cognitive abilities. This study is a quasiexperiment research. The population in this study is all students of grade IV SDN 050660 Kwala Bingai Stabat in academic year 2017/2018 which consists of three classes. The sample is selected by cluster random sampling of two classes. The instruments used are cognitive ability test, science process skill test and collaborative activity observation sheet. Data obtained from the research instrument were then analyzed using two-way anova in SPSS 22. The results showed that: students cognitive ability taught by collaborative-based inquiry learning model better than students taught by direct Instruction model (sig. $0.000<0.05$ ), students cognitive ability with high science process skills is better than students with low science process skills (sig. $0.000<0.05$ ), and there is an interaction between the two of learning models with the level of science process skills in influencing students cognitive abilities (sig. $0.037<0.05$ ).
\end{abstract}

Keywords - Inquiry Learning Model; Collaborative Learning; Science Process Skills

\section{INTRODUCTION}

The more rapid development of science and technology, the demands of teachers increasingly complex given the increasing number of things that must be handled by teachers in implementing a good educational process. The science-learning paradigm of the 21 st century is studentcentered, constructive, contextual, investigative, and prioritizing problem-solving [1]. Science learning should emphasize the mastery of concepts through a series of scientific processes [2] Science should be taught by learning that enables students to develop their capabilities and can build their own concepts. Science learning not only emphasizes conceptual understanding but needs to be applied to enable students to discover knowledge or concepts through their own experience by making observations, experiments and discussions [3].

Students are said to master a concept if the student has been able to perform a series of mental processes called cognitive processes. These cognitive processes include Bloom's taxonomy level from remembering, understanding, applying, analyzing, evaluating and creating. All these abilities are often referred to by the term cognitive ability. A good quality of education is obtained by applying all levels of the cognitive domain in every learning [4]. Cognitive ability is closely related to thinking skills, especially highorder thinking [5]. Cognitive ability is the term used to describe all mental activity associated with perception, thought, memory, and information processing that allows one to gain knowledge [6]. Cognitive ability is the result that can be seen due to the activity of obtaining information or knowledge. Cognitive ability can be obtained based on information seeking activities whose results can be seen [7]. To train students' thinking skills, a learning plan is required that facilitates their learning needs. Benjamin S. Bloom divides the cognitive domain into six hierarchically arranged levels (1) knowledge, (2) understanding, (3) application, (4) analysis, (5) synthesis, and (6) judgments [8].

Lessons learned by teachers in the classroom have not provided optimal results. Learning is more teacher-centered 
characterized by only a small percentage of all students who follow active learning activities. Learning activities are interspersed with question and answer, only followed actively by some students only. This shows that the learning process passively. Teachers more dominate the learning activities while students only as recipients of knowledge.

Characteristics of passive students in the classroom makes learning only one way of the teacher to the students. The lack of student responses to learning suggests that learning in the classroom can not draw attention to learning. This is because there are no activities undertaken by the students in addition to hearing the teacher explain the learning materials. Teachers do not raise aspects of the science process skills (SPS) in the learning process. Whereas in studying science is very necessary scientific activities for the subject matter can be better understood and meaningful for students, not just memorizing. In addition, students easily forget the material that has just received. This can be seen when the questioning is done at the end of the lesson, most students are unable to answer and more silent. The learning process that is dominated by the teacher and the low ability of students thinking causes unused students in training their cognitive ability. Then, the teacher does not understand the various variations of the learning model, so that when teaching, the teacher only gives the material directly without applying a particular learning model. This certainly makes students become bored quickly in following the learning.

The process of learning in schools is still textual ie learning by focusing only on mastery of the material on textbooks. Teachers only use books as the only source of learning. Students only memorize the facts of the book they use without understanding the intent of the information. His cognitive abilities are not trained to solve problems through a series of scientific activities. This will certainly result in the low ability of students to understand the concepts learned. These problems affect the weakness of the learning process and the weakness of students' cognitive abilities, thus affecting the learning outcomes. One alternative to overcome these problems is through inquiry learning model. Inquiry learning model is a series of learning activities that emphasize the critical and analytical thinking process to seek and find the answer to a question in question. This model emphasizes the searching and finding process. Students play a role in finding and finding their own subject matter, while teachers act as facilitators and counselors to learn. So that the process of teaching and learning will provide better effectiveness in improving student mastery of the subject matter. (3) Formulate the hypothesis, (4) Collect data, (5) Test the hypothesis, (6) Formulate the conclusion.
[9]. Inquiry learning model can be applied to students individually or collaboratively. Collaborative learning is a learning where students learn from each other and work together in small groups to improve the achievement of joint learning outcomes in learning [10]. The collaborative based inquiry-based inquiry model is a learning model that emphasizes learning activities that involve the active participation of students working together in groups to solve problems through searching and finding activities.

A process approach may give students the opportunity to participate in the process of discovery or to construct a concept as a process skill [11]. The process of performing activities related to science is usually called the science process skills. Skills in the process of science need to be developed because it contains cognitive, manual, and social skills. In addition, process skills need to be developed in science learning because process skills can help students learn to develop their thoughts, give students the opportunity to make discoveries, improve memory, provide intrinsic satisfaction when children have succeeded in doing something, help students learn basic concepts of science. Scientific process skills encourage students to discover for themselves the facts, concepts of knowledge and cultivate the attitudes and values demanded [12]. Indicators of the science process skills are (1) observing, (2) grouping, (3) interpreting, (4) predicting, (5) communicating, (6) asking questions, (7) proposing hypotheses, (8) 9) using the tools / materials / sources, (10) applying the concept, (11) carrying out the experiment [11].

Elementary teaching materials that require in-depth attention in relation to the Style material. In this material the students can not just memorize the concept without knowing how its application in real life. Students need to be directly involved in finding and discovering the concept of Style, so that what they learn can be understood and become meaningful for students. The aim of this study is to determine: whether the students cognitive ability taught by collaborative-based inquiry learning model better than the students taught by direct instruction model, whether the students cognitive ability with high science process skills, and whether there is interaction between the two learning models.

\section{METHOD}

This study is a quasi-experiment research. The population in this study is all students of grade IV SDN 050660 Kwala Bingai Stabat in academic year 2017/2018 which consists of three classes. The sample is selected by cluster random sampling of two classes. The instruments used are cognitive ability test, science process skill test and collaborative activity observation sheet. Data obtained from 
the research instrument were then analyzed using two-way anova in SPSS 22.

\section{RESULT AND DISCUSSION}

The test results were done by the two-way ANAVA with the General Linear Model (GLM) Univariate SPSS 22.0 which can be seen in Table I.

TABLE I. TWO-WAY ANAVA RESULT

\begin{tabular}{lccccc}
\hline Source & $\begin{array}{c}\text { Type III } \\
\text { Sum of } \\
\text { Squares }\end{array}$ & df & $\begin{array}{c}\text { Mean } \\
\text { Square }\end{array}$ & F & Sig. \\
\hline Model & 0.386 & 1 & 0.386 & 53.037 & 0.000 \\
\hline SPS & 0.288 & 1 & 0.288 & 39.577 & 0.000 \\
\hline Model * SPS & 0.034 & 1 & 0.034 & 4.599 & 0.037 \\
\hline
\end{tabular}

Data of anava test results in Table I used to answer the hypothesis proposed in this study. Here is a discussion of the results of the hypothesis test.

\section{A. The Effect of Collaborative-Based Inquiry Learning Model and Direct Learning towards Student Cognitive Ability}

After the data obtained from the research results, then the next stage is done to analyze the results. Preliminary analysis conducted on the results of the cognitive ability of students is to see the comparison of pretest and postes data in the experimental class and control class. Figure 1 shows a comparison of students 'cognitive abilities based on the students' pretest-postes grade of the experimental and control classes.

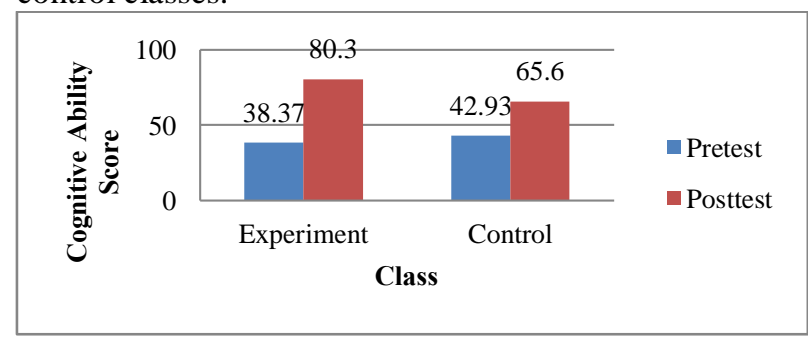

Fig. 1. Comparison of Pretest-Postes Data of Experiment Class and Control Class

From Figure 1. above can be seen the average increase of cognitive ability of students before and after being treated. The experimental class experienced an average increase of 41.93 while the control class experienced an average increase of 22.67. Based on these data it can be concluded that the improvement of students' cognitive abilities taught by collaborative based Inquiry model is better than the control class taught by direct learning model. Furthermore, to find out the magnitude of the average increase in students' cognitive abilities, the $\mathrm{N}$-gain values of the two classes can be summarized in Table II.
TABLE II. GAIN NORMALIZED

\begin{tabular}{ccc}
\hline Class & Mean Gain Value & Category \\
\hline Experiment & 0.68 & Medium \\
\hline Control & 0.41 & Medium \\
\hline
\end{tabular}

From Table II. obtained the value of $\mathrm{N}$-gain for the experimental class of 0.68 in the medium category, while in the control class obtained the $\mathrm{N}$-gain value of 0.41 with the medium category. These results indicate that the increase in the average of $\mathrm{N}$-gain of the two classes in different categories, although being in the same category, but the average gain value in the experimental class is higher than the average control class gain value with the difference of 0.27 . When viewed from the results of posttes and student gain values obtained in the experimental class and control class can be known the difference. This difference is seen from the average score obtained by the experimental class that is equal to 80.30 while the control class is 65.60 . In addition, the difference can also be seen from the gain calculation results obtained that the experimental class obtained an average score of 0.68 while the control class obtained an average score of 0.41 . The results of variance analysis in Table I. obtained the significance value of the learning model of $0.000<0.05$ so that the results of hypothesis testing reject $\mathrm{HO}$ or receive $\mathrm{Ha}$ in the level of alpha $5 \%$.

Based on these results it can be concluded that students who are taught by collaborative-based inquiry learning model get better average cognitive ability score than students who are taught by direct learning model.Through this inquiry students become more motivated to participate actively in learning activities. This is caused by several things, such as inquiry learning model involves more learners to be active and cooperate in discussions and practicum [13]. Inquiry learning model makes it easier for students to convey information so that the process of learning in the classroom becomes innovative and not boring [14]. The inquiry learning model requires students to think critically and creatively in solving problems and building new knowledge [15]. Through the model of inquiry learning students are involved mentally and physically to solve a problem given the teacher so that students will be accustomed to being scientific in solving a problem [16]. The learning process can run well certainly can not be separated from the role of teachers in providing stimulation to students to participate actively in learning activities and use their thinking skills. In addition it facilitates students in using learning resources and directing students when experiencing difficulties.

In this study inquiry learning models are applied with collaborative based. Collaborative learning is a learning activity that is carried out by collaborating in pairs or groups that involve active participation of students in working together to solve problems through searching and finding activities. The implementation of collaborative learning allows the exchange of ideas between members in groups 
where this not only increases students' learning interests but also improves critical thinking skills.

\section{B. Differences in Cognitive Ability of Students with High Scientific Process Skills and Low Scientific Process Skills}

The data of students' science process skill was obtained from the result of the essay test which students answered after two learning meetings. Based on the data of students' science process skills that have been collected, students are then grouped into two groups: groups of students with high science process skills and groups of students with low science process skills. Students who have high science process skills are students who get a value greater or equal to the median while students who have low science process skills ie students who scored less than the median. After determining the level of science process skills then grouped the value of students' cognitive ability gain based on high science process skills and low science process skills. In summary, the comparative value of students' cognitive abilities based on the skill level of the process of science can be seen in Figure 2.

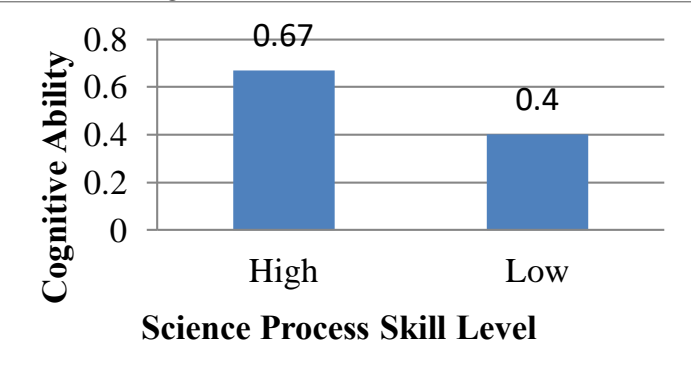

Fig. 2. Cognitive Ability of Students Based on Science Skills Process Level

The data cognitive abilities of students based on the level of science process skills can be known the difference. This difference is seen from the average score gain of cognitive ability obtained by the students that is based on high science process skill level of 0.67 while at the level of low science process skills of 0.40 So it can be concluded that the cognitive abilities of students who have high scientific process skills better than students with low science process skills. The result of variance analysis in Table I. obtained the value of the science process skill significance of 0.000 . Because the sig value. $0.000<0.05$ so that the result of hypothesis testing reject $\mathrm{HO}$ or accept $\mathrm{Ha}$ in level of alpha $5 \%$, meaning there is significant difference between cognitive ability of student having high science process skill with student having low science process skill.

During the learning process, the results of the observations show that students with high science process skills seem more active, respond more quickly and want to think more optimally in the learning process. In addition, in the experimental activities of students with high science process skills are able to perform well and help their friends who have difficulty understanding. While the group of students who have low science process skills seem less active, rarely respond and less willing to think more leverage in learning activities. In addition, when experimenting with students with low process skills get bored quickly and give up if facing difficulties in implementing them.

The science process skill is related to cognitive ability because students use their thoughts and knowledge in conducting science activities. The science process skill is not a hand skill using tools but a process thinking skill by using scientific processes [11]. The ability of each student is varied, some have high scientific process skills and some have low science process skills. Students with high science process skills can make good guesses and interpret data well. In addition, students with high science process skills can use the different senses to collect facts with more leverage. Students with high science process skills can solve problems in learning through the science process better. The science process skill positively influences the conceptual mastery [17]. Mastery of the concept relates to the acceptance of some information or material that can be used as a solution in analyzing, solving problems and interpreting an observed phenomenon. Students with high science process skills will certainly have better cognitive abilities than students with low science process skills. While students who have low science process skills tend to be less able to think and reason well, and very weak in doing science activities. Students with high academic ability will have better process skills than students with low academic ability [15].

Thus, based on the findings of the research that has been done and the existing theory shows that high process skills affect students' cognitive abilities better than low process skills.

\section{Interaction Between Learning Model and Skill of Science Process on Student Cognitive Ability}

The result of variance analysis in Table I was obtained by significance value of Model * SPS by 0.037 . Because of the sig value. $0.037<0.05$ so that the results of hypothesis testing reject $\mathrm{HO}$ or accept $\mathrm{Ha}$ in the level of $5 \%$ alpha means there is an interaction between the two models of learning with the level of science process skills in influencing students' cognitive abilities.

The result of interaction between the learning model and science process skill in influencing students' cognitive ability can be presented in graphical form. Figure 3 shows 
the graph of the interaction between the learning model and the science process skills on students' cognitive abilities.

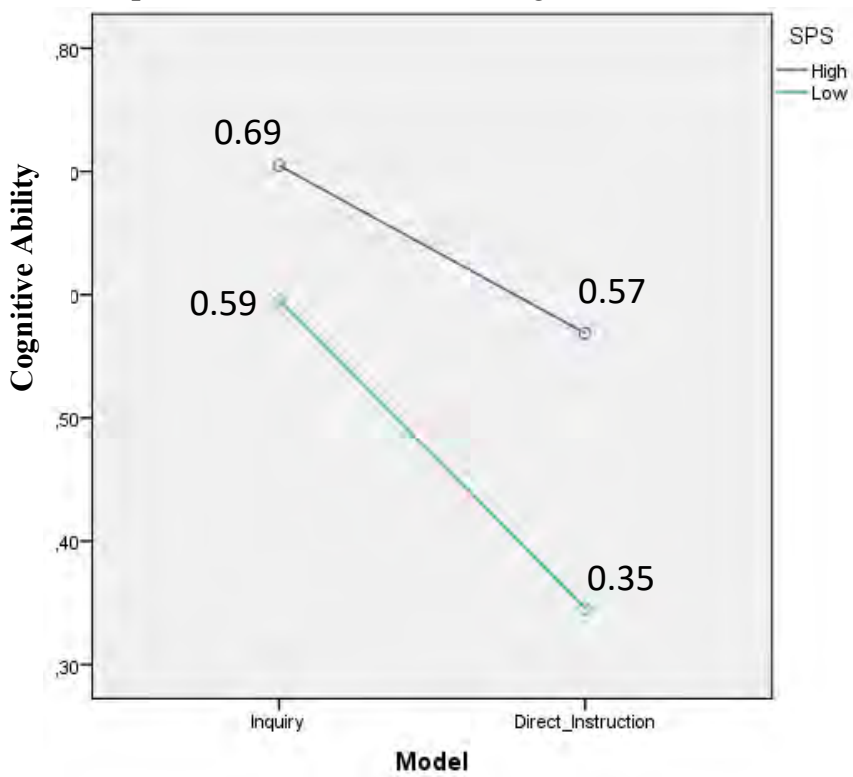

Fig. 3. Interaction Between Collaborative-Based Inquiry Learning Models and Direct Learning with Skills of the Process of Science in Influencing Students' Cognitive Ability

The graph above is an interaction pattern between the learning model and the science process skill of students' cognitive abilities. The $\mathrm{x}$-axis denotes both instructional models, whereas the $y$-axis represents the average value of cognitive ability with a high-skill science process variable and low-process science skills. The interaction is a condition in which the collaborative-based inquiry learning model and direct learning model and high science process skills and low science process skills contribute simultaneously to simultaneously affect students' cognitive abilities. When taught by collaborative-based inquiry models, students with high-tech science process skills and low-process science skills have the means to develop their knowledge and promote group co-operation.

This is a way to develop a way of learning active student learning by finding and investigating the concepts studied, hence the results obtained will be durable in memory and not easily forgotten students. The inquiry learning model is a learning model that emphasizes the analytical critical thinking process to seek and find out for themselves the answer to a questionable problem [9]. Inquiry learning model emphasizes maximal student activity to seek and find, so that in the learning process the students not only acts as the recipient of the lesson through a verbal explanation of the teacher, but the role to find itself the essence of the subject matter.

Students with high science-process skills will provide better cognitive learning outcomes if taught in collaborative- based inquiry learning models, because students with high science-process skills will make the most of their search for, linking and linking the materials taught to them. Through high science process skills, students together with their group friends will struggle to solve learning problems, so become accustomed in developing the ability to think in understanding learning, in the end the material can be mastered properly to obtain maximum cognitive learning results.

The application of collaborative-based inquiry learning model to students with low science process skills will cause the students to find difficulties in solving their learning problems. This is because the student has the characteristics of preferring to receive directions from the teacher on concepts and principles. In addition, lack of ability in acting actively, critically and analytically to utilize all existing learning resources and less able to find solutions or problem solving learning. Students with low science process skills if taught by collaborative-based inquiry model will have difficulty in building their knowledge, because students with low science process skills have inadequate logic or lack the ability to understand facts and concepts well. Students' cognitive structure with low science process skills requires time and a longer learning process to understand a subject matter. Students with low science process skills will have difficulty in resolving the given questions

Implementation of direct learning model is done by delivering verbal subject matter [9]. If applied to students who have high science process skills will lead to boredom and saturation because students are not required to think. In direct learning, students only accept and listen to material that teachers have prepared without feeling any challenge in developing the subject matter. The skill of the science process is limited to hearing and recording what the teacher has to say. This can suppress the development of students' science process skills, which can result in less than optimal cognitive abilities. However, for students with low science process skills, the application of a direct learning model is not too problematic, because students only read and memorize material that has been prepared by the teacher without having to think again. In this case, the student only hears the teacher's explanation and notes the important material as a series of learning process. However, students with high-tech science skills who are taught by direct learning models can get better grades from students with low science process skills. This is because students with high scientific process skills have better thinking ability than students with low science process skills. Based on the description above can be understood that there is interaction 
between the learning model with the level of science process skills to the cognitive abilities of students.

\section{CONCLUSION}

Based on the results of research and discussion, it can be concluded that students cognitive ability taught by collaborative-based inquiry learning model better than students taught by direct Instruction model (sig. 0.000 $<0.05$ ), students cognitive ability with high science process skills is better than students with low science process skills (sig. $0.000<0.05$ ), and there is an interaction between the two of learning models with the level of science process skills in influencing students cognitive abilities (sig. 0.037 $<0.05)$.

\section{References}

[1] Y. Wibowo, A. Widowati \& K. Rusmawati. 2013. Peningkatan Kreatifitas dan Kemampuan Kognitif Siswa Melalui Outdoor Learning Activity. Bioedukasi, 6(1):49-62

[2] A. Budiyono \& Hartini. 2016. Pengaruh Model Pembelajran Inkuiri Terbimbing terhadap Keterampilan Proses Sains Siswa SMA. Wacana Didaktika, 4(2):141-149

[3] R. Hidayah \& P. Pujiastuti. 2016. Pengaruh PBL Terhadap Keterampilan Proses Sains dan Hasil Belajar Kognitif IPA Pada Siswa SD. Jurnal Prima Edukasia, 4(2):186-197

[4] N. Vidayanti, T. Sugiarti, D. Kurniati. 2017. Analisis Kemampuan Kognitif Siswa Kelas VIII SMP Negeri 11 Jember Ditinjau dari Gaya Belajar Dalam Menyelesaikan Soal Poko Bahasan Lingkaran. Kadikma, 8(1):137-144

[5] H. Susana E. S. \& Sriyansyah. 2015. Analisis Didaktis Berdasarkan Kemampuan Kognitif dan Keterampilan Berpikir Kritis Siswa pada Materi Kalor. Jurmal Penelitian \& Pengembangan Pendidikan Fisika, 1(2):39-43

[6] M. Arpan, S. Bibi \& D. Sulistiyarini. 2016. Hubungan Kemampuan Kognitif dengan Kemampuan Psikomotor Mahasiswa dalam Mempersiapkan Diri Untuk Workshop Komputer Prodi PTIK. Jurnal Pendidikan Informatika dan Sains, 5(1):82-95

[7] Sukholifah. 2014. Kemampuan Kognitif Siswa Menurut Gagne pada Materi Himpunan Ditinjau dari Kemampuan Matematika. Mathedunesa, 3(3):246-251

[8] Khadijah. 2016. Pengembangan Kognitif Anak Usia Dini: Teori dan Pengembangannya. Medan: Perdana Publishing

[9] M. Hosnan. 2014. Pendekatan Saintifik dan Kontekstual dalam Pembelajaran Abad 21. Bogor: Ghalia Indonesia

[10] A. A. S. P. M. Dewi \& N. W. Rati. 2017. Penerapan Pendekatan Keterampilan Proses untuk Meningkatkan Hasil Belajar IPA Siswa Kelas V. Jurnal Ilmiah Sekolah Dasar, 1(2):83-90

[11] M. Tawil \& Liliasari. 2014. Keterampilan-Keterampilan Proses Sains dan Implementasinya dalam Pembelajaran IPA. Makasar: Badan Penerbit UMN

[12] S. Wulanningsih, B. A. Prayitno, R. M. Probosar. 2012. Pengaruh Model Pembelajaran Inkuiri Terbimbing Terhadap Keterampilan Proses Sains Ditinjau Dari Kemampuan Akademik Siswa SMA Negeri 5 Surakarta. Pendidikan Biologi, 4(2):33-43

[13] S. Sumarni, B. B. Santoso \& A. Suparman. 2017. Pengaruh Model Pembelajaran Inkuiri Terbimbing terhadap Hasil Belajar Kognitif Peserta Didik di SMA Negeri 01 Manokwari. Jurnal Nalar Pendidikan, 5(1):462-471

[14] S. W. R. Nasution, N. Bukit \& E. M. Ginting. 2016. Pengaruh Model Pembelajaran Inkuiri Terbimbing dan Kreativitas terhadap Kognitif Tinggi. Jurnal Pendidikan Fisika, 5(2):101-105

[15] T. A. W. Hartati, A. D. Corebina \& H. Suwono. 2015. Pengaruh Model Pembelajaran Inkuiri Terstruktur dan Siklus Belajar 5E terhadap Keterampilan Proses Sains dan Hasil Belajar Kognitif
Siswa pada Kemampuan Akademik Berbeda. Jurnal Pendidikan Sains, 3(1):22-30

[16] H. P. S. Lubis, E. Djulia \& S. Edi. 2016. Pengaruh Mode Pembelajaran Inkuiri dan Kooperatif terhadap Kemampuan Kognitif Siswa pada Materi Animalia di SMA Negeri 11 Medan. Jurnal Pendidikan Biologi, 5(3):167-173

[17] H. Siswono. 2017. Analisis Pengaruh Keterampilan Proses Sains Terhadap Penguasaan Konsep Fisika Siswa. Momentum Physics Education Journal, 1(2):83-90 